\title{
Teaching about the Spirit of Trust on Someone Who has Perception of Anomic Suicide: As a Solution to Generate Transcendental Trust on Personality
}

\author{
Syamsul Alam ${ }^{1}$
}

\begin{abstract}
Suicide is an event that often occurs among the community due to a personal psychological disorder, both due to depression, mental disorders and so on, especially depression due to economic, social and chronic diseases experienced by a person and lasts for a long time as a result they assume hat matters It inhibits all activities and life and even considers itself no longer useful because of the lack of intake of the values of the spirit of trust of his religion, as a result someone wants to end his life with suicide, the purpose of this study is to determine the effect of the teachings of belief (the spirit of trust) on anomic suicidal perceptions that aim to reduce the anomic suicide rate of a person in the community, the type of research used is library research by conducting a literature study both books, journals and other references relating to the object under study, based on the results of research that the teachings of trust (the spirit of trust) can reduce one's suicidal perceptions that have implications for reducing the desire to commit suicide.
\end{abstract}

Keywords — Trust, Perception, Anomic Suicide

\section{I.INTRODUCTION}

Anomic suicide is a psychological illness that is rife in society due to depression due to economic, social and severe (chronic) illnesses suffered by a person so that he often considers himself useless anymore and even considers that the subject is an obstacle in every activity as a result of trying to end his life by suicide.

According to Nicksen and Sings that the helplessness that causes someone to commit suicide is due to a depressed mood and feeling guilty[1]. The depressive phase collaborates with acts of suicide originating from bipolar disorder which gives rise to a dominant mood. In Indonesia every year there are 10,000 people who die from suicide and every hour one person dies and is the second leading cause of death in adolescence and adulthood. According to Benedetto Saraceno, director of the Department of mental health, and WHO data, the average suicide death in Indonesia is 24 deaths per 100,000 populations. If the Indonesian population is 220 million, there will be 50,000 cases of deaths due to suicide[2].

This is a serious problem that has not been resolved until now so it requires a solution to minimize

${ }^{1}$ Syamsul Alam Faculty of Syariah and law, Islamic State University Sunan,Kalijaga, Yogyakarta, 55264, Indonesia, email: syamuinsuka@gmail.com these actions. In suicide there are stages of ideas which are the process of contemplation of a concept and process that is passed without taking action or an action by which a person will not express his thoughts to commit suicide if not suppressed[3]. Darmaningtyas said that one of the causes of suicide in the community was due to economic factors in dealing with the difficulties of life. various methods carried out by someone in committing suicide, Suryani explained that there are several methods of suicide carried out by someone namely hanging himself, drinking poison, stabbing himself, plunging himself and finally burning himself[4].

the spirit of trust is an action that includes positive behavior which implies a reaction, that is transcendental trust, how a person perceives, behaves, speaks and works. There is an action variable that explains how a person should look, behave, talk and work. This variable gives rise to a reaction and brings benefits in overcoming suicidal perceptions, the teaching cycle of trust (the spirit of trust). relies on the teachings of the Koran and Hadith, therefore all components in action synergize with one another to build a transcendental trust[4].

Anomic (without norms, obscurity of norms) is a moral state when the person concerned loses his ideals, goals and norms in his life, values that bring motivation to the direction of his behavior, have no effect anymore, various events can cause it, disasters that befall someone, until who have cheered and disciplined him have been destroyed[5].

For example a person whose entire life force is mobilized for the welfare of his family or success in his career or the collection of assets, then experiences disasters resulting in not only experiencing an emotional crisis in the form of mental stress but also a crisis of values such as responsibility, loyalty, hard work, achievement of honesty that stops stimulate and curb, it is not only the calamity that causes anomies but the huge profits or the achievement of ideals can bring the same effect[4]. According to Herdaeta that the factors that cause suicide are, depression (sad, guilty, loss of life's passion and feeling useless), bipolar disorder (sadness that goes on quickly), schizophrenia (crazy expectations that do not match reality), aneroxia and bulimia nervosa (decreased intentional food intake), self-mutilation and substance abuse[6]. 
The $1^{\text {st }}$ International Conference on Global Development - ICODEV

November $19^{\text {th }}, 2019$, Rectorate Building, ITS Campus, Sukolilo, Surabaya, Indonesia

As far as the author's search there has been no study related to the perception of anomic suicide, therefore this study discusses the influence of the teachings of beliefs on anomic suicidal perceptions aimed at minimizing anomic suicidal perceptions in society.

\section{METHOD}

The type of research used is library research by conducting a literature study both books, journals and other references relating to the object under study, library research is research conducted on literature with the desired research material, whether through reading, seeing, listening or through the internet[7]. Research on literature studies is related to theoretical references both values, culture and norms that develop in certain situations and has an important role because each study must involve a study of scientific literature[8].

library research steps include: having ideas related to the research topic, finding information related to the topic, looking for the required reading material and classifying it, reading and making research notes, evaluating and enriching reading material and classifying reading material later[9]. Data collection and processing techniques are done by collecting primary, secondary and tertiary materials and are processed in a systematic and orderly manner while the technical analyst is analyzing the object variables under study and relying on the facts that occur in the field then drawing conclusions based on the analysis and data obtained.

\section{RESULTS AND DISCUSSION}

\section{A. Anomic Suicide Factors}

Several factors cause anomic suicide that is; psychological factors (depression, stress, anxiety, helplessness and drug abuse, family factors (divorced parents, history of suicide) social factors (friends, social, close relationships and negative experiences)[10]. According to Putu Wilasa that the cause of suicide is due to lack of understanding of religion so that it takes a shortcut as a solution to resolve life problems[11]. Lack of understanding of religious values that affect the personality of the anomic perpetrators so that when faced with problems do not know what to do and also do not know where to complain and ask for help therefore the teachings of belief (spiritual) aims to draw closer to the Creator as a place to complain and ask for help[12].

TABLE. 1

SUICIDE FACTORS OF THESIS FK-UAND

\begin{tabular}{|l|l|l|l|}
\hline Biology & Psychology & Family & General \\
\hline Mentally & hopeless & depressed & Social isolation \\
\hline Depresion & inferiority & $\begin{array}{l}\text { Changes in } \\
\text { family } \\
\text { structur }\end{array}$ & Drugs and alcohol \\
\hline $\begin{array}{l}\text { Chronic } \\
\text { illness }\end{array}$ & Lost identity & $\begin{array}{l}\text { Law } \\
\text { economy }\end{array}$ & Bully \\
\hline Genetic & $\begin{array}{l}\text { Fear of } \\
\text { humalition }\end{array}$ & Harassment & Abortion \\
\hline $\begin{array}{l}\text { hormonal } \\
\text { changes }\end{array}$ & $\begin{array}{l}\text { The death of } \\
\text { the best } \\
\text { solution }\end{array}$ & Career & Less friendship \\
\hline Stressful & $\begin{array}{l}\text { Acts of } \\
\text { violence }\end{array}$ & Inconsistent & Khinship \\
\hline $\begin{array}{l}\text { seksual } \\
\text { identity }\end{array}$ & Egosentrisme & $\begin{array}{l}\text { History of } \\
\text { suicide }\end{array}$ & $\begin{array}{l}\text { Achievement } \\
\text { failed }\end{array}$ \\
\hline
\end{tabular}

\section{B. Relationship of Teaching of Trust and Perception of Anomic Suicide}

Anomic perceptions owned by someone tend to make an assessment of themselves and their environment based on beliefs and lead to the assumption that anomis has hampered all life so as to judge that anomic suicide is the best solution to end his life. due to lack of intake of belief values (spiritual) that affect how a person perceives, speaks and behaves so that it will cause a transcendent reaction from the anomic perpetrator not to commit suicide.

According to the mental health recovery institute that spiritual-based beliefs are a reason for continuing to live as long as they are connected with the spiritual and purpose of life[13]. because the doctrine of trust is life in a person that gives rise to strength[14]. the values of trust lead someone to get out of a difficult situation and will find a way of life[15]. There is no life without trust because spiritual values will sell in a person[16]. According to Dadang Hawari states that the teachings of trust must be prioritized because of changing social conditions because this will provide ethical ethics, and a healthy living guide that is eternal without the teachings of trust then someone will be easily blown away and stressed due to very rapid social changes[17]. Gede Made Suardana, a criminologist at Udayana University, said that it is necessary to have a better understanding of the teachings of belief related to character and norms in social life as a preventative measure for suicide[11].

\section{Suicide Rate in Indonesia}

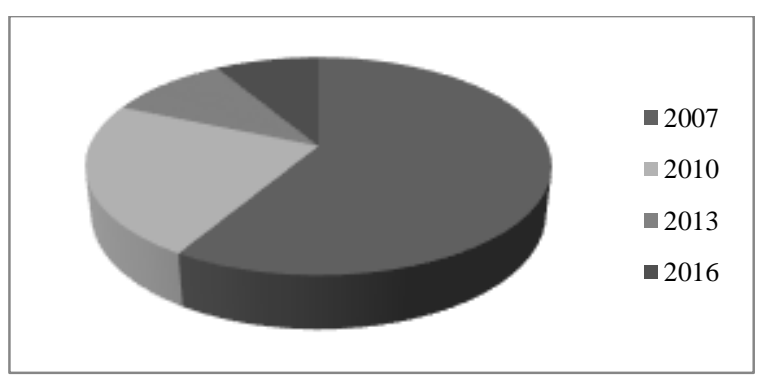

Figure 1: Our World In Data

The graph above shows a decrease in suicide rates from year to year, however, there needs to be a method as a preventive measure in preventing anomic suicide

\section{Implications The spirit of Trust on Perception of Anomic Suicide}

The values of the teachings of trust aim to foster survival so that they are able to face threats, challenges and obstacles both externally and internally in life as the formation of one's identity. So that the teachings of faith become important as a guide and guide of life[18].

President of the American Psychiatric Association stated that religious institutions are one of the institutions that are important for human health and well-being because they can work constructively in improving the level of welfare and mental health both 
individually and in groups, Hawari said in guiding the complex health of the human psyche with all his desires and interests should be the commitment of the teachings of trust can be used as a spiritual power as a protective power in dealing with all the problems of life[12]. The teachings of trust will shape the personality of the self based on understanding and belief and become the basis as a step to prevent deviant behavior[19].

\section{CONCLUSION}

Public anomic perception that leads to anomic suicide is a phenomenon that is difficult to eliminate because there is no appropriate way or solution in accommodating the problem, the doctrine of belief in anomic perception is a strategy to minimize the perception of anomic suicide because it has influence and implications for someone's good attitude ways of looking, talking and behaving that cause a person's transcendent reaction to the personality to not commit anomic suicide.

\section{AKNOWLEDGEMENTS}

I would like to thanks so much highly the first to a lmighty God over the strength and healthy has given so I can do activity particulary writing away, the second both mother and father as well as to both wife and inlaws has been support me to writing this paper till done and the third to ICODEV ITS has been providing the agenda so I elicit a vast insight, buddies and so on, I conviction and hopely this paper could give contribute to the community, nation and state

\section{REFERENCES}

[1] Tience Debora Valentina and Avin Fadilla Helmi, "Powerlessness and Suicide Behavior," Meta-Analysis, Psychol. Bull., vol. 24, pp. 123-135, 2016.

[2] Franky Febryanto Banfatin, "Identification of Increased Social Functioning and Reducing Suicide Risk for Patients with Mental Health Disorders Bipolar Disorder in Medan City Through Psychosocial Mentoring Therapy."

[3] Lita Arfandiyah dan Kusuma Dewi, ""Relationship between Loneliness and the Idea of Suicide in Teenagers with Divorced Parents", Clin. Psychol. Ment. Heal., vol. 02, p. 03, 2013.

[4] L. Suryani, "'Handling Suicide Cases in Bali' Handout at the Seminar Addressing Suicide Cases in Bali"," Denpasar, 2006.

[5] Alex Sobur, "General Psychology." Bandung: CV Pustaka Media, 2003

[6] Moh. Rosyid, "Contribution of Religious Instructors in Minimizing Suicide,'” J. Stain Suci, vol. 5, no. December, p. 136, 2014.

[7] Drafting Team, “Law Writing Guideline." Yogyakarta: FH UMY 2007.

[8] L. widha and A. R. A. Citra Widya Astuti, "” Play Therapy as a Form of Counseling Management"," HISBAH J. Guid. Couns. Islam. Da'wah, vol. 16, no. 1, June, 2019.

[9] Alfiani Yunia Amiati, "Study of Literature Concerning the Theory and Practice of Counseling,", J. UNESA BK, vol. 03, p. $01,2013$.

[10] N. Aulia, “'Analysis of the Relationship Between Suicide Risk Factors, Idea of Suicide in Adolescents in Rengat City, Indragiri Hulu Regency," Andalas University, Padang, 2016.

[11] I Wayan Romi Sudhita. Sudhita, "Suicide Behavior Among Students, (Descriptive Analysis of Bali Post Coverage in 2006 2009)," J. ISSN 1829-5282, p. 29.

[12] Nur Hamid Ashofa, "'Reality Therapy for Handling Trauma (Post Traumatic Stress Disorder) in Bullying Victims at the
Women's Social Protection and Rehabilitation Center,"” HISBAH J. Guid. Couns. Islam, vol. 16, no. 1, p. June, 2019.

[13] Mutmainnah, "“Analysis of Depression incidents and Suicide Risk using the Buddy App on Adolescents in the Makassar City Area,", UIN Alauddin Makassar, 2018.

[14] Ian Frowe, ""Professional Trust"," Br. J. Educ. Stud., vol. 53 no. Maret, p. 1, 2005.

[15] Anica Leon-Weil and Carol Hewitt, "“Trust as a Teaching Skill," YC Young Child., vol. 63, no. 5. September, 2008.

[16] Teck-Hua Ho and Keith Weigelt, “"Trust Building among Strangers"," Manage. Sci., vol. 51, no. April, p. 4, 2005.

[17] Rosyad, "'The influence of religion on mental health,"” J. AlSyifa Al-Qulub, vol. 1, no. July, p. 21, 2016.

[18] Andri Hernandi, "Efforts to Revitalize the Value of the Doctrine of Belief in God Almighty."

[19] Muflih, "'Reproductive Health Knowledge Associated with Teenage Self Confidence To Avoid Free Sex,"' J. Nurs., vol. 5, no. January, p. 23, 2015. 